\title{
VYBRANÉ PROBLÉMY ČESKO-POLSKÉ TERMINOLOGIE SPORTU ${ }^{1}$
}

\author{
Representative Problems of Czech-Polish Sport Terminology
}

Keywords: sport, Czech language, Polish language, terminology, etymology, semantics Contact: Masarykova univerzita; pikulova.jana@gmail.com

\section{1 Úvod}

Tématem př́spěvku je představení analýzy vybraných lexémů sportovní terminologie, která je součástí zkoumání rozdílnosti v pojmenovávání v českém a polském sportu. Prvotní myšlenka vychází z pozorování, že v obou výše zmíněných jazycích existují malé i velké rozdíly v označení částí hřišt', hráčů, pravidel, výstroje a výzbroje aj. $\mathrm{V}$ jednom jazyce se pro konkrétní předmět užije domácí výraz, kdežto na straně druhé výpůjčka. Kromě toho označující výrazy nemají vždy stejnou šiři významu.

\section{Tvorba slovní zásoby}

Tvorba slovní zásoby je založena na sběru výrazů, které jsou vloženy do tabulek podle sportů. V jednom sloupci se nachází české výrazy a v druhém jejich polský překlad.

\section{Způsob výběru dvojic k další analýze}

Po sebrání vyčerpávajícího množství výrazů týkajících se jednoho sportu, následuje výběr těch dvojic jednotek, které budou podrobeny hlubší analýze. Mimo náš zájem se dostávají páry, které mají na obou stranách bud’ domácí pojmy, nebo výpůjčky, ale ze stejných jazyků, tedy stejného původu. Naopak se do popředí dostávají následující dvojice: ty, které mají na jedné straně domácí výraz a na druhé straně výpůjčku; ty, které mají na obou stranách výpůjčku, ale jedná se o výpůjčky z dvou různých jazyků; ty,

\footnotetext{
1 Tento text vznikl v rámci řešení projektu Specifického výzkumu MUNI/A/1348/2020 Teoreticko-aplikační a lexikografická podpora překladu ve slovanských jazycích (Ústav slavistiky FF MU).
} 
které mají sice na obou stranách výpůjčky stejného původu nebo domácí výrazy, avšak šíre jejich významu není stejná.

\section{Rozbor jednotek}

Níže představujeme způsob detailního rozboru jednotek na př́íkladu termínů z fotbalu a hokeje. Každý výraz obsahuje původ, vysvětlení významu a př́iklad užití z českého ${ }^{23}$ nebo polského ${ }^{4}$ korpusu.

\section{Fotbal}

\section{polsky PILKA NOŻNA, FUTBOL}

piłka nożna - původ: $\mathrm{z}$ angl. football

= sportovní soutěž, které se účastní dvě družstva o jedenácti hráčích, která se snaží $\mathrm{v}$ určitém čase získat, co nejvíce bodů za vstřelení míče do soupeřovy branky ${ }^{5}$

„Po raz pierwszy w historii mistrzostwa świata w pitce nożnej zorganizuja dwa kraje."

futbol - původ: $\mathrm{z}$ angl. football

„Goeteborg musi rozpoczać ofensywnie $i$ uważać na polskie kontry. Dlugie pitki do szybkich napastników zawsze wyróżniaty polski futbol. Lech Poznań opanowat tę sztukę dobrze i będzie z pewnościa czekat na bład Szwedów."

\section{česky FOTBAL, KOPANÁ}

fotbal - původ: $\mathrm{z}$ angl. football

„Kariéru Baroš naštěstí zatím ještě neukončil, někdejši vitěz Ligy mistrů zastává nyní, už ve svých třiatřiceti letech, roli náhradníka v Mladé Boleslavi. Vypjaté emoce fotbal každopádně neopouštějí, kvůli nim se vlastně hraje. "

\footnotetext{
${ }^{2}$ Křen, M., Cvrček, V., Čapka, T., Čermáková, A., Hnátková, M., Chlumská, L., Jelínek, T., Kováríková, D., Petkevič, V., Procházka, P., Skoumalová, H., Škrabal, M., Truneček, P., Vondřička, P., Zasina, A. SYN2015: reprezentativni korpus psané češtiny. Dostupné z: http://www.korpus.cz (2021-04-25).

${ }^{3}$ Kř̌en, M., Cvrček, V., Henyš, J., Hnátková, M., Jelínek, T., Kocek, J., Kováŕíková, D., Křivan, J., Miličcka, J., Petkevič, V., Procházka, P., Skoumalová, H., Šindlerová, J., Škrabal, M. SYN2020: reprezentativni korpus psané češtiny. Dostupné z: http://www.korpus.cz (2021-04-20).

${ }^{4}$ Pęzik, P., Przepiórkowski, A., Bańko, M., Górski, R. L., Lewandowska-Tomaszczyk B. (ed.) Wyszukiwarka PELCRA dla danych NKJP: Narodowy Korpus Języka Polskiego. Dostupné z: http://www.nkjp.uni.lodz.pl/ (20213-28).

${ }^{5}$ Piłka nożna. Dostupné z: https://sjp.pwn.pl/szukaj/pi\%C5\%82ka\%20no\%C5\%BCna.html (2021-04-21). 
kopaná - od českého kopat

„Dvacet osm firemnich týmů změř́ dnes své sily na Strahově v benefičním fotbalovém turnaji v malé kopané. Koná se totiž 7. ročník Sue Ryder Charity Cupu. Touto jedinečnou formou podpoři fotbalisté Domov Sue Ryder a jeho poslání - di̊stojnou péči o seniory. Turnaj se koná ve Fotbalovém centru mládeže Strahov. “

Označení piłka nożna je lexikální kalk neboli doslovný překlad původního anglického výrazu football. Můžeme se také setkat s často používanou zkráceninou „piłka“, Idziemy zagrać w piłkę. V tomto př́padě je ale nutné znát kontext, protože samotné označení piłka nemusí odkazovat pouze na fotbal, ale také na futsal (pl. piłka halowa) nebo házenou (pl. piłka ręczna). Kromě označení piłka nożna se používá také výraz futbol, ale méně často. Ovšem přesnější informace k frekvenci užití těchto dvou výrazů nám nejsou známy, protože se nám zatím nepodařilo najít dostupný frekvenční slovník polského jazyka, tak jak je pro češtinu dostupný v rámci korpusu na př́slušných internetových stránkách. Stejně jako u lexému piłka, tak i u jednotky futbol je třeba znát kontext, i když ve velké většině př́ípadů jde v polském prostředí o fotbal, může však jít rovněž o rugby, americký fotbal a další.

V českém prostředí jednoznačně převažuje pro označení tohoto sportu výraz fotbal, pocházející také z anglického football, zde jde však pouze o výpůjčku nikoliv o překlad původního názvu. Naproti tomu existuje ještě výraz kopaná, který se neužívá $\mathrm{v}$ až tak vysoké míře jako fotbal. Najdeme ho spíše v projevech sportovních komentátorů jako vhodné synonymum nebo také v menší míře u fanoušků, avšak u osob, které fotbal př́liš nezajímá, se s tímto termínem setkáváme spíše zřídka, protože kromě jiného působí i archaicky. Podle frekvenčního slovníku se od dvacátých let 20. století užíval téměř výhradně výraz kopaná, kdežto v šedesátých letech se trend obrátil a od té doby se v 95 \% př́ípadů užívá termín fotbal. ${ }^{6}$ Stejně jako v př́padě polského futbolu bychom i zde mohli požadovat bližší specifikaci, jestli snad nejde o americký fotbal, ale vzhledem k oblíbenosti, to není nutné. Ještě je třeba podotknout, že výraz kopaná se zachoval v názvu halového sportu malá kopaná, který je teda také označován jako malý fotbal.

Z hlediska použití tedy není možné říct, že výraz futbol je přesným ekvivalentem českého výrazu fotbal, naopak českému fotbalu odpovídá polské piłka nożna. Zároveň také nemůžeme říct, že by futbol byl nějak spjatý s českou kopanou, nebot' česká kopaná jako označení fotbalu je výraz méně užívaný a spíše archaický, kdežto polský výraz futbol toto zabarvení nemá.

\footnotetext{
${ }^{6}$ Cvrček, V., Vondřička, P. SyD. Dostupné z: http://syd.korpus.cz (2021-04-20).
} 


\section{polsky POZYCJA SPALONA, SPALONY}

- polský výraz vycházející ze staršího významu „pokažený, zničený“7

\section{I. spálený, popálený ${ }^{8}$}

„Pierwsza historyczna wzmianka o Brodnicy (nazwa od brodu) pochodzi z XIII w. Istniejacy tu zamek krzyżacki, spalony w 1298 przez Litwinów, potem odbudowany, stanowit siedzibę komtura."

\section{II. vyzrazený (vyzvědač); zkompromitovaný ${ }^{9}$}

,-- Dokąd wrócisz, oszalateś? Jesteś spalony.

- Nie - powiedziat. - Spalony zostat agent udajacy Hansa Klossa."

III. v hokeji, fotbale, ragby - porušení pravidel, kdy při přihrávce míče druhému hráči stejného týmu se mezi druhým hráčem a soupeřovou brankou nenachází žádný ze soupeřova týmu ${ }^{10}$

„Bramka nie powinna być uznana. Piłka odbiła się od ręki Haesslera, a Klinsmann byt chyba na spalonym - powiedziat trener Boliwii, Bask Xabier Azkargorta."

\section{polsky OFSAJD, OFSAJDOWA PULAPKA}

$=$ ofsajdová past

„Zagranie to rodzi wiele kontrowersji, podobnie jak sam ofsajd, gdyz zdarzaja sie sytuacje, kiedy to ewidentny spalony zostaje nieodgwizdany przez sędziego, bądź też kiedy zostaje odgwizdany gdy faktycznie go nie $m a . " 11$

„Pułapka ofsajdowa (ang. offside trap) - zagranie wpiłce nożnejpolegajace na wyjściu linii obrony do przodu i pozostawieniu napastnika (bądź innego zawodnika / zawodników) drużyny przeciwnej na pozycji spalonej, co kończy się odgwizdaniem

\footnotetext{
${ }^{7}$ „Znacznie ciekawszy jest przymiotnik (imiesłów) spalony, powiązany z czasownikami palić, spalić. Jako termin (czasem w wyrażeniu pozycja spalona) funkcjonuje on nie tylko w piłce nożnej, ale też w rugby i hokeju. Co więcej, także $\mathrm{w}$ innych dyscyplinach sportu znane są sfrazeologizowane połączenia typu spalić bój (rwanie, podrzut) w podnoszeniu ciężarów, spalić skok (w dal, w trójskoku), spalić rzut (dyskiem, młotem, oszczepem). Wygląda więc na to, że spalony to 'zepsuty, nieudany', por. w Uniwersalnym stowniku języka polskiego: „spalić, położyć dowcip”. Sięgając głębiej w przeszłość, należałoby wziąć pod uwagę frazeologizm coś spalito na panewce 'coś się nie udało, zakończyło się niepowodzeniem, zawiodło'.“ Bańko, M. Polska terminologia pitkarska. Dostupné z: https://sjp.pwn.pl/poradnia/haslo/polska-terminologia-pilkarska;11960.html (2021-04-21).

${ }^{8}$ Oliva, K., Balowski, M. Polsko-český slovnik. Voznice: Leda, 2012.

${ }^{9}$ Spalony I. Dostupné z: https://wsjp.pl/index.php?id_hasla=17066\&ind=0\&w_szukaj=spalony\# (2021-03-13).

${ }^{10}$ Spalony. Dostupné z: https://sjp.pwn.pl/szukaj/spalony.html (2021-03-13).

${ }^{11}$ Pulapka ofsajdowa. Dostupné z: https://juventus.fandom.com/p1/wiki/Pu\%C5\%82apka_ofsajdowa\# (2021-0313).
} 
przewinienia $i$ przerwaniem akcji ofensywnej, lub przynajmniej koniecznościa rozegrania akcji innym wariantem. "12

\section{česky OFSAJDOVÁ POZICE, OFSAJD}

původ: $\mathrm{z}$ angl. offside

- používá se také česká varianta postavení mimo hru, ale ne ve fotbalu, ale např̀. u hokeje ano

„Před koncem sice Wágner srovnal, ovšem kvůli ofsajdu Františka Rajtorala sudi Miroslav Zelinka uznaný gól po delši konzultaci s pomezním Jiř́m Jiřikem zrušil. "13

Pozycja spalona označuje ofsajdovou pozici čili situaci, kdy se některý hráč nachází na polovině soupeře, blíže k soupeřově brance než míč i než předposlední hráč soupeře. Takováto situace sama o sobě není porušením pravidel, pokud se však hráč v ofsajdové pozici zapojí do hry ve chvíli, kdy se jeden z jeho spoluhráčů dotkne míče, jedná se o ofsajd a hra je přerušena. ${ }^{14}$ Pokud se zaměříme na výraz spalony, tak ten má mnoho významů i mimo sportovní oblast. Jde o něco, co se spálilo, osobu, která byla vyzrazena nebo nějak zkompromitována, nebo také o osobu pod vlivem marihuany. Použití ve sportu odkazuje na dřívější význam, který označoval něco pokaženého, nepodařeného viz napřs. spalić dowcip.

Český výraz ofsajd pochází z anglického offside čili postavení mimo hru. Je zajímavé, že ve fotbale se užívá výhradně termínu ofsajd, naproti tomu např. v hokeji už se užívá obou termínů rovnocenně, tedy ofsajd i postavení mimo hru.

Můžeme říci, že pozycja spalona, spalony a ofsajdová pozice, ofsajd jsou ideálními ekvivalenty a není důvod, aby zde při překladech docházelo k nějakým problémům. Je třeba ale zmínit, že v polštině se objevuje výraz ofsajd, ale to jen marginálně. Běžně se však užívá ve slovním spojení pułapka ofsajdowa (č. ofsajdová past) a není možné říci pułapka spalona.

\footnotetext{
12 Op. cit. Pułapka ofsajdowa.

${ }^{13}$ Ofsajd. Dostupné z: https://www.korpus.cz/slovo-v-kostce/search/cs/ofsajd?lemma=\&pos= (2021-04-22).

${ }^{14}$ Ofsajd. Dostupné z: https://cs.wikipedia.org/wiki/Ofsajd (2021-04-22).
} 


\section{Hokej}

\section{polsky KIJ}

původ: z psl. *kyjь 'kladivo, kyj'15

\section{I dlouhý, tlustý, jednoduchý klacek ${ }^{16}$}

„,W mroku trudno już było dostrzec cokolwiek, ale poczuła, że coś dotyka jej twarzy, siegnęła tam ręka i chwyciła kij, trzymała mocno, a Konus wyciagat ja z bagna, juz jest na brzegu, poczuła pod brzuchem twardy grunt, puściła kij, już była bezpieczna."

bambusowy $\sim$, drewiany , krzywy

$\sim$ od łopaty, $\sim$ od miotły, $\sim$ od siekiery

\section{II dřevěná nebo kovová tyč speciálního tvaru používaná ve sportu ${ }^{17}$}

$\sim$ baseballowy, $\sim$ bilardowy, e golfowy, $\sim$ hokejowy; e narciarskie, $\sim$ do bilarda, $\sim$ e do golfa, e do krykieta ${ }^{18}$

„,- Poproszę kij do hokeja, ten za dwieście.

Już widziałem siebie mknacego po lodzie z moim nowym kijem, ale, jak na razie, znajdowatem sie jeszcze na Pradze, wśród budek i kramów. ”

\section{česky HOKEJKA}

původ: $\mathrm{z}$ angl. hockey

= sportovní náčiní v podobě hole, kterou hráči strkají puk (popřr. míček) do soupeřovy branky $^{19}$

„Adam byl skvělý brankár̆ - nepochybně by byl jedním ze žhavých kandidátư na vysokoškolský tým -, pak ale před šesti měsíci přestal. Prostě zničehonic. Odložil hokejku, lapačku i masku a prohlásil, že konči.."

\section{česky HŮL}

původ: z psl. *golъ ,holý ${ }^{* 20}$

\footnotetext{
${ }^{15} \mathrm{Kij}$. Dostupné z: https://wsjp.pl/index.php?id_hasla=24442\&id_znaczenia=2945423\&l=13\&ind=0 (2021-0325).

${ }^{16}$ Op. cit. Kij.

${ }^{17}$ Drabik, L., Sobol, E. Stownik języka polskiego PWN. Warszawa: Wydawnictwo naukowe PWN, 2007.

${ }^{18}$ Op. cit. Kij.

${ }^{19}$ Nechybujte.cz. Dostupné z: nechybujte.cz (2021-03-26).

${ }^{20}$ Hůl. Dostupné z: https://en.wiktionary.org/w/index.php?title=h\%C5\%AFl\&oldid=54704079 (2021-03-26). 
= obvykle rovná tyč, sloužící jako opora při chůzi, módní doplněk či zbraň hokejová , florbalová , baseballová , golfové e, slepecká , francouzské e

„Bílá slepecká hůl většinu lidí pohne $k$ nezištné pomoci nevidomému člověku. “

„Ve 22. minutě už diváci ve slušně zaplněné hale aplaudovali vstřelené brance, té ale předcházela vysoká hůl Jakuba Nakládala, zkoumání u videa proviněni proti regulím potvrdilo. “

Polský výraz kij vychází z praslovanského výrazu pro kladivo, kyj a označuje jakoukoliv dlouhou, jednoduchou tyč. Používá se i ve významu násady k zahradnímu nebo stavebnímu náčiní, nebo jako topor k sekeře. Druhý význam výrazu kij jen více specifikuje význam první a zaměřuje se pouze na sport. Ovšem ani v tomto př́padě okruh označovaných předmětů není tak úzký jako v př́ípadě české hokejky.

Český výraz hưl už nemá tak úzký význam, pochází z praslovanského výrazu holý a neoznačuje čistě jednu věc, naopak můžeme tento výraz najít v souvislosti se sportem hokejová hưl, golfové hole, jako pomůcku pro nevidové slepecká hůl nebo jako pomůcku pro zraněného člověka francouzské hole. U výrazu hůl je ve velké většině př́padů, pokud to není jasné z kontextu, nutné doplnit adjektivum, které výraz blíže specifikuje.

V českém prostředí se pro náčiní, které používají hráči ledního hokeje, užívají dva výrazy, avšak výraz hokejka je rozšířenějšíi, a to především mezi laiky a fanoušky sportu, kdežto mezi sportovními komentátory a lidmi více spjatými s hokejem jsou oba výrazy rovnocenné. Zajímavostí je, že ač se tyto dva významy mohou zaměňovat, v př́ípadě překročení pravidel, kdy hráč hraje s vysoko zdviženou hokejkou, užívá se pro tuto situaci ustálené spojení hra vysokou holí, nikoli hokejkou.

Pro shrnutí tedy můžeme ř́íci, že polský výraz kij má ve vztahu ke sportu v češtině dva protějšky. Výraz hůl, který je obecnějšího charakteru a dá se užít i mimo oblast sportu, a hokejka, která už úzce odkazuje na sport, konkrétně na lední nebo pozemní hokej a na florbal.

\section{polsky KRĄżEK}

původ: z psl. *krǫgъ 'něco zakrouceného, svinutého, svitek, kolo, kruh, předmět ve tvaru kola, koule 21

= zdrobnělina od „kruh“

\footnotetext{
${ }^{21} \mathrm{Krag}$. Dostupné z: https://wsjp.pl/index.php?id_hasla=33986\&ind=0\&w_szukaj=kr\%C4\%85g (2021-03-27).
} 
Ia krążek światła - povrch vyznačený kruhovitou linií

Ib krążek np. sera - plochý předmět

„Biszkopty przekroić na trzy krążi, każdy krążek nasaczyć sokiem ananasowym i przełożyć kremem. W krem wcisnać osaczone i pokrojone ananasy."

Ic płyta - deska z umělé hmoty, na kterou se zapisuje zvuk, abychom jej později mohli přehrát

„Testy odczytu z plyt $C D-R$ rozłożyliśmy na trzy osobne pomiary, uwzględniajace kolor powierzchni odblaskowej płyty. Jako nośnik $R W$ wykorzystaliśmy krążek Hawlett Packarda $z$ nagrana kopia wspomnianego wcześniej Nortona."

\section{Id krążek do hokeja}

„Niespetna pięć minut później rozegrat doskonata akcje z obrońca Kelly Buchbergerem i jeszcze raz posłat krążek do bramki rywali.'

IIa krążek znajomych - okruh známých

IIb krążek zainteresowań - okruh zájmů

\section{česky PUK}

\section{I sportovní náčiní ve tvaru disku z černé gumy, používané v ledním hokeji ${ }^{22}$}

„Z angl. puck, jež přišlo z Kanady kolem r. 1900. Původ nejasný - snad z angl. poke ,št'ouchnout, strčit (holí)‘, či snad žertovně podle homonymního puck «čertík, skřítek, šotek»" 23

„Sám jel na prázdnou branku, když hosté ve snaze vyrovnat odvolali brankárée. Protihráči ho faulovali, takže nemohl vystřelit a puk těsně minul branku."

\section{II záhyb na kalhotách ${ }^{24}$}

původ: z něm. Bug od slovesa biegen - ohýbat ${ }^{25}$

„Lehce zachmuřený pohled a precizně vypilované detaily nenechávají nikoho na pochybách, že Audi A8, ten rezervovaný perfekcionalista, si nechal opèt ušít oblek podle poslední módy. Nic na něm netrčí, nohavice maji správnou délku a puky jsou pěkně zažehlené. “

\footnotetext{
${ }^{22}$ Puk. Dostupné z: https://cs.wiktionary.org/wiki/puk (2021-03-27).

${ }^{23}$ Rejzek, J. Český etymologický slovnik. Praha: Leda, 2015.

${ }^{24}$ Op. cit. Krag.

${ }^{25}$ Op. cit. Rejzek, J. 


\section{III rostlinný pupen ${ }^{26}$}

„Pro 4 osoby si pripravíme: $500 \mathrm{~g}$ hovězi roštěné kousek čerstvého zázvoru asi 5 lžic sójové omáčky 1 velkou cibuli 2 velké mrkve $200 \mathrm{~g}$ mražených fazolových lusků (převařených) 2 puky bílé čekanky asi 4 lžice oleje asi $150 \mathrm{ml}$ hovězího vývaru sưl mletý černý pepř. “

\section{česky KOTOUČ}

původ: „Jen č. a slk. (kotúč), úzce spojeno s kotoul, přesný způsob tvoření však není jasný. “27

\section{Ia plochý předmět kulatého tvaru}

„Využití vody snižuje teplotu broušeného povrchu a minimalizuje prašnost. Pracuje se s brusnými kotouči různé hrubosti, nakonec se povrch doleští lešticím kotoučem."

„Maximální fáze zatměni nastane ve 22:12, kdy bude měsični kotouč procházet nejtemnějši částí zemského stínu, a skonči tři minuty po třiadvacáté hodině. “

\section{Ib protáhlá věc svinutá do kulatého tvaru}

„,Mandžiró a jeho druhové se usadili na přidi za velkým kotoučem lodního lana a vyménili Džúsukemu obvaz na noze."

\section{Ib hokejový puk}

„Síla a zkušenosti, to jsou hlavní rozdíly v porovnání s juniorkou. Hráči si umí kotouč ohlídat. Vědí, kdy mají vystřelit, a kdy puk naopak podržet. “

Krążek, zdrobnělina od výrazu krąg, pochází z praslovanského výrazu *krogъ, kterým se nazývá předmět kulatého tvaru, kolo, kruh. Zde označení hokejového puku odkazuje na jeho kruhový tvar, podobně jako je tomu u českého výrazu kotouč. Slovo krążek má však mnoho významů a je-li vytrženo z kontextu, neodkazuje pouze na sportovní předmět, ale např́klad na kruh světla, kruh sýra, $C D$, nebo v přeneseném slova smyslu na okruh známých nebo okruh zájmů.

V češtině se pro kulatý předmět z černé gumy používá výraz puk, který vychází ze stejného předmětu z angličtiny z výrazu puck. Slovo puk má zároveň i jiné významy, které ale nesouvisí se sportem a ani nijak svým tvarem hokejový puk nepřipomínají. Máme tedy puk ve významu záhyb na kalhotech nebo také jako pupen na rostlině.

\footnotetext{
${ }^{26}$ Op. cit. Krąg.

${ }^{27}$ Op. cit. Rejzek, J.
} 
Dalším označením černého předmětu v hokeji je výraz kotouč. Běžní mluvčí častěji užívají termín puk, ale mezi komentátory a osobami pohybující se v hokeji je i kotouč rozšířen, ale není zastoupen $\mathrm{v}$ tak velké míře. Výraz kotouč je ale používán i mimo sport. Jedná se o plochý předmět kulatého tvaru, jako např. brusný kotouč, kotouč pily, kotoučové brzdy, kde je pokaždé odkazováno na tvar předmětu.

Můžeme tedy říct, že v obecném slova smyslu by polský krążek lépe odpovídal českému kotouči, ale pro vhodný překlad tuto dvojici nemůžeme spojit, protože kotouč je vhokejovém prostředí méně užívaný než dominantní puk. Proto vhodnými ekvivalenty jsou krążek-puk.

\section{Závěr}

Na základě výrazů, které do této chvíle prošly naší analýzou, není možné říci, že by v některém z jazyků převažovaly výpůjčky. Avšak je zde patrné, že pokud je termínem výraz domácí, je zde větší pravděpodobnost, že šiřre jeho významu bude větší než u výpůjčky.

Př́klady představené $\mathrm{v}$ tomto př́spěvku jsou jen zlomkem $\mathrm{z}$ výzkumu, který bude dále pokračovat $\mathrm{v}$ dalších sportech analýzou podobně charakteristických jednotek. Jestliže se podaří sesbírat velké množství slov, bez ohledu na to, jestli budou dále analyzována, jako vedlejší produkt by mohl vzniknout česko-polský slovníček sportovních pojmů. Podle našeho zjištění v posledních letech žádný takový slovník $\mathrm{v}$ této jazykové kombinaci nevznikl a jeho vznik by tedy mohl pomoci nejen sportovním fanouškům, ale také např. sportovním komentátorům.

\section{Summary}

The article focuses on introducing representative problems of Czech-Polish sport terminology. The aim is to show that in these two languages, there is a different extent of representation of domestic expressions and borrowed expressions from other languages. Moreover, as demonstrated with examples of football and ice hockey terminology, there is also a different scope of meaning of these expressions which can complicate the choice of appropriate equivalent while translating. 


\section{Literatura}

Drabik, L., Sobol, E. Słownik języka polskiego PWN. Warszawa: Wydawnictwo naukowe PWN, 2007.

Oliva, K., Balowski, M. Polsko-český slovník. Voznice: Leda, 2012.

Rejzek, J. Český etymologický slovník. Praha: Leda, 2015.

\section{Elektronické zdroje}

Bańko, M. Polska terminologia piłkarska. Dostupné z: https://sjp.pwn.pl/poradnia/ haslo/polska-terminologia-pilkarska;11960.html (2021-04-21).

Cvrček, V., Vondřička, P. SyD. Dostupné z: http://syd.korpus.cz (2021-04-20).

Hůl. Dostupné z: https://en.wiktionary.org/w/index.php?title=h\%C5\%AFl\&oldid $=54704079$ (2021-03-26).

Kij. Dostupné $\quad$ z: https://wsjp.pl/index.php?id_hasla=24442\&id_znaczenia= $2945423 \& 1=13 \&$ ind $=0$ (2021-03-25).

Krag. Dostupné z: https://wsjp.pl/index.php?id_hasla=33986\&ind=0\&w_szukaj $=\mathrm{kr} \% \mathrm{C} 4 \% 85 \mathrm{~g}(2021-03-27)$.

Křen, M., Cvrček, V., Čapka, T., Čermáková, A., Hnátková, M., Chlumská, L., Jelínek, T., Kováŕíková, D., Petkevič, V., Procházka, P., Skoumalová, H., Škrabal, M., Truneček, P., Vondřička, P., Zasina, A. SYN2015: reprezentativni korpus psané češtiny. Dostupné z: http://www.korpus.cz (202104-25).

Křen, M., Cvrček, V., Henyš, J., Hnátková, M., Jelínek, T., Kocek, J., Kovářríková, D., Křivan, J., Milička, J., Petkevič, V., Procházka, P., Skoumalová, H., Šindlerová, J., Škrabal, M. SYN2020: reprezentativní korpus psané češtiny. Dostupné z: http://www.korpus.cz (2021-04-20).

Nechybujte.cz. Dostupné z: nechybujte.cz (2021-03-26).

Není kibic jako kibic. Dostupné z: http://www.akcr.cz/txt/neni-kibic-jako-kibic (202104-20).

Ofsajd. Dostupné z: https://cs.wikipedia.org/wiki/Ofsajd (2021-04-22).

Ofsajd. Dostupné z: https://www.korpus.cz/slovo-v-kostce/search/cs/ofsajd?lemma $=\&$ pos $=(2021-04-22)$. 
Pęzik, P., Przepiórkowski, A., Bańko, M., Górski, R. L., LewandowskaTomaszczyk B. (ed.) Wyszukiwarka PELCRA dla danych NKJP: Narodowy Korpus Języka Polskiego. Dostupné z: http://www.nkjp.uni.lodz.p1/ (2021-3-28).

Pitka nożna. Dostupné z: https://sjp.pwn.pl/szukaj/pi\%C5\%82ka\%20no\%C5\%BC na.html (2021-04-21).

Puk. Dostupné z: https://cs.wiktionary.org/wiki/puk (2021-03-27).

Pułapka ofsajdowa. Dostupné z: https://juventus.fandom.com/p1/wiki/Pu\%C5\%82apka _ofsajdowa\# (2021-03-13).

Spalony. Dostupné z: https://sjp.pwn.pl/szukaj/spalony.html (2021-03-13).

Spalony I. Dostupné z: https://wsjp.pl/index.php?id_hasla=17066\&ind=0\&w _szukaj=spalony\# (2021-03-13). 